UDC 621.389

\title{
Research of Sensor Systems in Temperature Changes
}

\section{The Main Directions of Application of Sensor Systems in Internet of Things Systems}

\author{
A. A. Mosisa, ORCID 0000-0002-6160-2641 \\ Chen Xiangcai, ORCID 0000-0002-2334-2156 \\ National Technical University of Ukraine "Igor Sikorsky Kyiv Polytechnic Institute", ROR 00syn5v21 \\ Kyiv, Ukraine
}

\begin{abstract}
Annotation-Direction included in the technology of "Internet of Things" to analyze the working of sensor systems in extreme areas, that is the properties and features of embedded control systems based on them, to identify the main problems of operation and features of sensors in smart - systems. The article considers the main types of sensors used in smart systems, the main alignments used in the design and creation of systems based on them, and experimentally evaluates the dependence of the speed of sound on air temperature.
\end{abstract}

Keywords — internet of things; sensor; smart system; embedded systems

\section{INTRODUCTION}

The term "Internet of Things" encompasses a large area of computer research. The term Internet of Everything (IoE) is also becoming widespread. A feature of the Internet of Things is the ability to connect to the Internet a variety of devices and systems that a person can use in their daily activities. All these things must be equipped with remote and direct control functions. Sensors and sensors that have the ability to process information coming from the environment, exchange it and perform various manipulations with the received data. Examples of the introduction of such technology are the "smart home" system, which includes: climate control and ventilation, control, adjustment and control of light, video surveillance system, security systems, fire control and alarm system control, multimedia control system, full automation of engineering production (sensors, touch panels, etc.). Also in recent years, actively implemented systems of smart transport, smart city and the like. There is a large number of scientific publications and works on this topic, which is the basis of this area. The purpose of this work is to present the results of the study of the structure of the Internet of Things using sensors and identify advantages and disadvantages during operation in domestic and industrial tasks on the example of an ultrasonic sensor based on the interference of sound vibrations. future.

There are concepts that will implement IoT in the near

The first concept is "preventive control": IoTs can predict the causes of accidents and reduced efficiency of equipment, as well as proposals to eliminate problems in the future. Thanks to IoT, you can run remote monitoring and monitor the operation of equipment online in real time, or control the production process in production using a touch panel.
The second concept is "remote diagnostics". IoT sensors can be used to diagnose the devices on which they are installed and automatically respond to changes in their status.

The third concept is "operations control". With the help of IoT you can control the full cycle of technological operations, control the movement of any devices and automatically monitor their characteristics and condition in real time.

The fourth concept is "process automation". IoT allows you to automate typical repetitive operations, increasing efficiency and saving time, quality of leisure, customer satisfaction, speed of continuous operation.

\section{TYPES OF SENSORS}

Several types of sensors used in smart systems are considered.

\section{A. Ultrasonic sensor}

Ultrasonic sensors are used in various fields: radio electronics, flaw detection, medicine, food industry, industrial production and security systems. They are designed to protect closed objects and emit danger signals when an exciting object (danger) appears. The principle of operation of ultrasonic sensors is based on the registration of changes in the ultrasonic field caused by the appearance of a person in a room or a fire. They are characterized by high sensitivity and a high level of false alarms, for example, large objects limit the action of such sensors, creating shielding areas ("dead zones") in which the sensors do not respond to danger. The reliability of such sensors depends on changes in the environment, for example, air currents generated by air conditioners and heaters can also cause the alarm system to malfunction. Therefore, these sensors are mostly used to protect small objects. In the simplest case, the sensor includes an acoustic emitter, a receiver and a signal processing unit. 
A piezoelectric ultrasonic transducer is used as the radiating and receiving element. From the output of the receiver, the signal enters the circuit of the signal processing unit, which, depending on the algorithm embedded in it, forms a message.

The following principles of operation are typical for devices of this type:

- the first principle based on the interference of ultrasonic vibrations. When the room is closed, the space controlled by the device is limited and a stable interference pattern is formed at the location of the receiver. When any object enters the room, the stability of the interference pattern is violated and an alarm is generated.

- the second principle is based on the use of the Doppler effect - changes in the frequency of mutual movement of objects. In addition to the above sensors, you can also select proximity detectors, which are designed to protect a specific place or possible place of penetration of danger.

\section{B. Ultrasonic sensors based on the interference of} sound vibrations

First of all, the detection systems of a moving object are built according to the scheme shown in Fig. 1, a.

The emitter $\mathrm{O} 1$ and the receiver $\mathrm{R} 1$ were placed on opposite walls of the room, under the ceiling (to reduce the impact of the interior).

The $\mathrm{O} 1$ emitter excited ultrasonic oscillations stable in frequency and amplitude in the space of the room. Receiver R1 converted the received from space ultrasonic signal into electric. Next, in the electronic device, this signal was amplified, detected and analyzed by amplitude. In case of change of amplitude of the received ultrasonic signal the alarm signal was formed. The block diagram of the ultrasonic detector is shown in Fig. 2.

Block diagram of an ultrasonic detector based on the interference of sound oscillations, consisting of A amplifier, $\mathrm{G}$ - ultrasonic oscillation generator, D - detector, PA - power amplifier, A - amplitude analyzer, AE alert element.

Movements in the room will change the path of the ultrasonic waves, and hence change the interference pattern. This will change the amplitude of the output signal of the receiver R1. By registering them, you can detect movement in a confined space. This method of detecting moving objects provides a very high sensitivity with high efficiency, because the wave from the oscillator $\mathrm{O} 1$ to the receiver R1 passes through the room by the shortest path, and therefore has the least attenuation. However, in real conditions, this system is virtually inoperable due to the extremely high probability of false positives. The system even responds to the flow of air, because the summation of the speed of sound with the speed of air will change the nature of the wave, which will be perceived by the receiver R1 as the movement of the object. To increase the stability of the system, the oscillator $\mathrm{O} 1$ and the receiver R1 are placed on the same wall (Fig. 1, b).

The wavelength double increase, which requires a significant increase in radiated power. But due to the fact that the wave passes through the air flow twice - back and forth, the increase in speed is mutually compensated, which increases the resistance of the device to false positives in conditions of relatively uniform air flows. In real conditions, air flows can be uneven. In addition, a significant contribution to the instability of the interference pattern in the real room make deformations, air currents, various vibrations and other factors. All this led to the fact that the security system, built on the principle described above, was inoperable.

\section{A. Ultrasonic proximity detectors}

Such detectors are designed to protect not the entire room, but only a specific, specific place, likely to identify a dangerous object. In fig. 3 shows a block diagram of an ultrasonic proximity detector, which consists of blocks of emitter, receiver, processing, control and notification.

The principle of operation of ultrasonic proximity detectors is that first packets of ultrasonic pulses are created at a certain frequency. These packets are then fed to an emitter with a frequency of $40 \mathrm{kHz}$. The sound wave from the transmitter propagates radially in the air at a speed of sound that is approximately $346 \mathrm{~m} / \mathrm{s}$ under normal conditions. This speed is somewhat affected by temperature and humidity, and it does not depend on pressure. Therefore, the speed of sound is almost independent of altitude. As the sound wave propagates along the radius, the signal intensity decreases inversely the square of the distance.

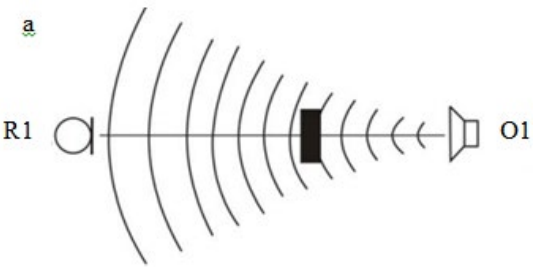

Fig. 1, a. Ultrasonic detection sensor

$\mathrm{b}$

$\mathrm{O} 1$

R1

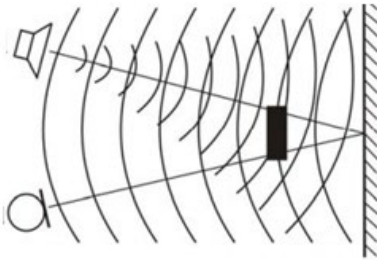

Fig. 1, b. Location of ultrasonic sensors

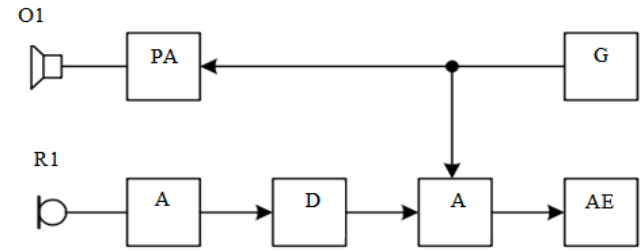

Fig. 2. Block diagram of an ultrasonic detector based on the interference of sound vibrations 


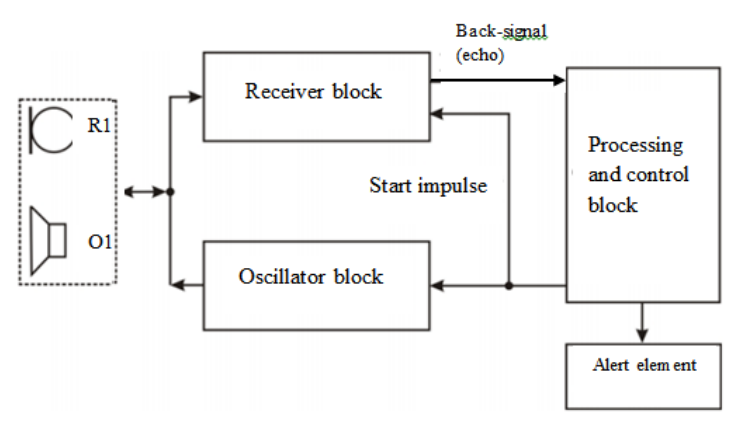

Fig. 3. Block diagram of an ultrasonic proximity detector

TABLE 1. TECHNICAL CHARACTERISTICS OF ULTRASONIC DETECTORS

\begin{tabular}{|c|c|c|c|c|c|}
\hline \multirow[t]{2}{*}{ № } & \multirow[b]{2}{*}{ Characteristic } & \multicolumn{4}{|c|}{ Type of detector } \\
\hline & & LH-US & $\begin{array}{c}\text { OMNI- } \\
\text { US }\end{array}$ & Echo-5 & $\begin{array}{c}\text { USD on } \\
\text { PSoC mi- } \\
\text { cro-con- } \\
\text { troller }\end{array}$ \\
\hline 1 & $\begin{array}{l}\text { Distance } \\
\text { range, } m\end{array}$ & $1-10$ & $5-14$ & $1-10$ & $0.1 \ldots 4-10$ \\
\hline 2 & $\begin{array}{l}\text { Frequency } \\
\text { range, } \mathrm{kHz}\end{array}$ & 40 & 40 & $30-50$ & $30-50$ \\
\hline 3 & Current, $\mathrm{mA}$ & $40-50$ & 33 & 30 & $25-5$ \\
\hline 4 & Voltage, $\mathrm{V}$ & $\begin{array}{l}120- \\
277\end{array}$ & 24 & $\begin{array}{l}10.6- \\
15\end{array}$ & $6-20$ \\
\hline 5 & $\begin{array}{l}\text { Sensor time } \\
\text { reaction, } \mathrm{s}\end{array}$ & - & - & 0.5 & 0.25 \\
\hline 6 & $\begin{array}{l}\text { Temperature } \\
\text { compensation }\end{array}$ & \multicolumn{4}{|l|}{ yes } \\
\hline 7 & $\begin{array}{l}\text { Temperature } \\
\text { range }\end{array}$ & $0 \ldots+40$ & $0 \ldots+40$ & $0 \ldots+50$ & $-25 \ldots+75$ \\
\hline
\end{tabular}

When a sound wave reaches an object, it is reflected in different directions depending on the shape of the object, its orientation and surface properties. After the reflected signal is detected (a sufficient number of reflected signal cycles is determined), the sensor turns off the receiver unit.

After that, depending on the method of operation of the sensor, the received signal is analyzed, and in case of presence of object the alarm signal is issued. For example, you can measure the propagation time of a sound wave and determine the distance to an object. If the distance is less than or greater than a certain set level, an alarm is triggered.

For devices of this type are characterized by two types of configuration of the structural placement of the emitter and the receiver of the ultrasonic signal (as in Fig.1): a detector with a separate emitter and receiver; detector with combined emitter and receiver.

In the first case, the ultrasonic signal from the emitter arrives at the receiver, and if no changes are observed in the sensor definition field, the entire system will be in a waiting state. Any decrease in the level of the signal coming to the receiver, or its absence, will cause the alarm to be activated (this may occur when the device fails).

With this arrangement, a fairly high level of system reliability is provided.

When the emitter and receiver are combined, the ultrasonic signal from the emitter enters the controlled area of the object of protection, is reflected and enters the receiver. Any object that appears in the path of the ultrasonic signal will trigger an alarm. In this mode, the signal from the emitter must be much stronger than in the first case.

Proximity detectors are convenient to use in the following places: through the room; at the exit; in front of a wall safe or an expensive painting; in the passage to the attic or basement; in any other place where the violator may pass.

The table shows the technical characteristics of some ultrasonic detectors.

For creating alarm system with increased reliability, high noise immunity and speed, it is necessary to develop new methods based on measuring the time parameters of the signals.

\section{SPEED OF SOUND AND ACCURACY OF MEASURE- MENT OF ULTRASONIC SENSORS}

Ultrasonic sensors operate on the principle of echolocation - the distance to the object is calculated based on the measurement of the time interval between the moments of sending and receiving the sound pulse and the speed of sound in the environment.

For gases, the formula for the speed of sound is:

$$
\begin{aligned}
& c=\sqrt{(\gamma k T / m)}=\sqrt{(\gamma R T / M)}= \\
& =\sqrt{\gamma R(t+273.15) / M},
\end{aligned},
$$

$\gamma$ - adiabatic index: $5 / 3$ - for monatomic gas; $7 / 5$ - for polyatomic gas (and for air); 4/3 - for else polyatomic gases; $k$ - Boltzmann constant; $R$ - universal gas constant; $T$ - absolute temperature in Kelvin; $t$ - absolute temperature in Kelvin; $m$ - absolute temperature in Kelvin; $M$ - molar mass.

One by one, the speed of sound in gases is close to the average speed of thermal motion of molecules and in the approximation of the constancy of the adiabatic exponent is proportional to the square root of the absolute temperature.

The formula for the speed of sound in air at pressure:

$$
c(t)=331 \sqrt{(1+t / 273)}
$$

$t$ - temperature in Celsius; $331 \mathrm{~m} / \mathrm{s}$ - sound speed in air.

The dependence shows that the speed of sound waves decreases with decreasing air temperature. Most manufacturers in the specification for ultrasonic sensors indicate the coefficient of temperature error, expressed in percent per one degree of temperature. Then, is $L=c t$ (3) the sensitivity distance can be corrected.

The wavelength of the sound is determined by the ratio:

$$
\lambda=c / f
$$

$\lambda$ - wavelength; $c$ - sound speed; $f$ - frequency.

In the case when the size of interference and heterogeneity in the environment significantly exceeds 
the wavelength of sound, the propagation of sound occurs according to the laws of geometric acoustics. If the interference can be compared with the wavelength (or less than it), a significant role begins to play the diffraction of waves, which is associated with the scattering of sound. These phenomena should be taken into account when choosing a sensor, especially to detect small objects and irregularities. For example, the wavelength at a speed of sound $344 \mathrm{~m} / \mathrm{s}$ (at normal conditions) for the frequency:

$40 \mathrm{kHz}-8.6 \mathrm{~mm} ; 180 \mathrm{kHz}-1.9 \mathrm{~mm} ; 400 \mathrm{kHz}-0.86 \mathrm{~mm}$.

\section{CONCLUSION}

The principles of functioning and features of operation of ultrasonic sensors of the security alarm system which work on the basis of interference of sound fluctuations are considered; their advantages and disadvantages are highlighted; the dependences of speed and accuracy of measurement of ultrasonic sensors are considered, the speed of sound on temperature in air under normal conditions is considered for using in technology of the internet of things.

\section{REFERENCES}

[1] A. M. Zungeru, "Design and development of ultrasonic notion detector", School of Electrical and Electronic Engineering, 2016, $13 \mathrm{p}$.

Надійшла до редакції 29 березня 2021 р.
[2] D. Caicedo and A. Pandharipande, "Ultrasonic arrays for localized presence sensing”, IEEE Sensors Journal, pp. 849-858, May 2012. DOI: $10.1109 /$ JSEN.2011.2161667

[3] Chukhraiev N.V., Vladimirov A.A., L.Vilcahuaman, W. Zukow, Samosyuk N.I., Chukhraieva E., Butskaya L.V. Application of ultrasonic waves, magnetic fields and optical flow in rehabilitation. Kiev Shupyk National Medical Academy of Postgraduate Education Pontifical Catholic University of Peru Radomsko High School SCM «Medical Innovative Technologies». 2017. - 324 p.

[4] D. Caicedo and A. Pandharipande, "Ultrasonic array sensor for indoor presence detection", 20th European Signal Processing Conference, 2012. pp. 175-179. ISBN: 978-1-4673-1068-0

URL: $\underline{\text { https://ieeexplore.ieee.org/document/6333985 }}$

[5] Saha, S., Ishraque, H., Islam, M.T., \& Rahman, M.A. IoT based smart home automation and energy management. In 2019 Thesis \& Report, BSc (Electrical and Electronic Engineering) (Department of Electrical and Electronic Engineering, Brac University) P. 85

[6] V. P. Horol's'kij, D. Ju. Kljuev, S. M. Korzhov "Intelektual'na sistema upravlinnja ta monitoringu robochih harakteristik tehnologichnogo obladnannja hlibobulochnih zavodiv" Visnik Hmel'nic'kogo nacional'nogo universitetu. Tehnichni nauki. No.6, pp.55-62, 2016. URL: http://journals.khnu.km.ua/vestnik/pdf/tech/pdfbase/2016/2016 6/(243)\%202016-6-t.pdf

[7] Li, W.; Cassandras, C.G. A minimum-power wireless sensor network selfdeployment scheme. In Proceedings of the 2005 IEEE Wireless Communications and Networking Conference, New Orleans, LA, USA, 13-17 March 2005; Volume 3, p. 1897-1902. DOI: $10.1109 /$ WCNC.2005.1424801 
УДК 621.389

\title{
Дослідження сенсорних систем в умовах змін температур
}

\section{Основні напрямки застосування сенсорних систем в системах Інтернету речей}

\author{
Мосиса A. A., ORCID 0000-0002-6160-2641 \\ Чень Сянцай, студент, ORCID 0000-0002-2334-2156 \\ Національний технічний університет України \\ «Київський політехнічний інститут ім. Ігоря Сікорського», ROR 00syn5v21 \\ Київ, Україна
}

\begin{abstract}
Анотація - Сенсорні системи розглядаються як такі, що можуть входити до складу інтегрованих об'єднань, з метою оптимізації та модернізації охоронних функцій. Такий підхід знаходить свою застосування у сучасних смарт - системах. Розглянуто напрямок, що входить до технології «Інтернет речей» 3 метою аналізу роботи сенсорних систем в умовах екстремального використання, а саме властивості і особливості роботи вбудованих систем керування на їх основі, з метою визначення основних проблем функціонування та особливостей роботи сенсорів у вбудованих системах. Розглянуто основні концепції, що визначають положення технології «інтернету речей», її склад та структуру. Визначено основні різновиди датчиків, їх характерні особливості, що впливають на можливість їх застосування у різноманітних системах, що формують смарт - системи, а саме ультразвукові датчики, принцип дії яких заснований на ресстрації зміни ультразвукового поля, викликаного появою досліджуваного об'єкта або небезпеки. Вони характеризуються високою чутливістю та високим рівнем хибних спрацювань, сенсори на основі інтерференції звукових коливань, що забезпечус дуже високу чутливість при високій економічності, оскільки хвиля від випромінювача до приймача проходить через приміщення найкоротшим шляхом, а отже має найменше загасання, проте в реальних умовах ця система практично непрацездатна із-за надзвичайно високої вірогідності помилкових спрацьовувань, ультразвукові детектори наближення, що забезпечують досить високий рівень надійності системи, їх характерні структурні моделі. Визначено основні різновиди типів сповіщувачів, основними характеристиками яких с діапазон робочих відстаней, діапазон робочих частот, струм споживання, напруга живлення, час реакції сенсора, наявність або відсутність температурної компенсації, діапазон робочих температур. В статті розглянуто основні співвідношення для сенсорів, що застосовуються в смарт - системах при проектуванні та створенні об'сктів на їх основі, а саме точність вимірювання ультразвукових сенсорів та довжини звукової хвилі, та експериментально оцінено залежність швидкості звуку від температури повітря. 3'ясовано, шо швидкість поширення звукових хвиль знижусться зі зниженням температури повітря. У разі, коли розмір перешкод і неоднорідностей в середовищі помітно перевищус довжину хвилі звуку, поширення звуку відбувається за законами геометричної акустики. Якщо ж перешкоди можна порівняти 3 довжиною хвилі, істотну роль починас грати дифракція хвиль, 3 якою пов'язано і розсіювання звуку. Дані явища слід враховувати при виборі датчиків особливо для виявлення дрібних об'єктів і нерівностей.
\end{abstract}

Ключові слова - інтернет речей; сенсор; смарт - система; вбудовані системи. 